\title{
Risk Assessment of Occupational Accident of the Riggers at PT X Surabaya
}

\author{
Penilaian Risiko Kecelakaan Kerja Oleh Juru Ikat di PT X Surabaya
}

\author{
Grace Stacyana Pasaribu \\ PT Kalbe Farma \\ Gedung Kalbe, Jalan Let. Jend Suprapto Kav 4 Jakarta 10510 Indonesia
}

\begin{abstract}
Introduction: PT. X in Surabaya is a company specialized in the provision of freight services, both domestically and internationally. The loading and unloading services at PT. X is performed 24 hours a day; thus, the company regulates 3-shift divisions each day. The services are done by moving containers from a ship to chassis trucks or the other way around by using a crane operated by the STS operator and riggers. The loading and unloading services are believed as highrisk activities, since the workers are exposed to falling, slipping, being struck down by materials or containers, or being squeezed. Methods: This study applies the cross-sectional design with the observational approach. The variables of this study comprise hazard identification, risk assessment, risk control, and residual risk. The variable of risk assessment is done by applying the qualitative method. The primary data is obtained through observation and interview, while the secondary data is acquired from the company profile. Results: In the hazard identification, one low-risk hazard, 11 moderate-risk hazards, and ten high-risk hazards are discovered. Conclusion: It can be affirmed that as much as $45.45 \%$ of high-risk hazard is found amongst the riggers, such as the hands are squeezed by mooring ropes, being crushed by containers, falling from the heights, falling into a ship hatch, and being struck down or hit by twist locks.
\end{abstract}

Keywords: loading and unloading, riggers, risk assessment

\section{ABSTRAK}

Pendahuluan: PT. X, Surabaya merupakan perusahaan yang bergerak dibidang pelayanan jasa angkutan barang, baik domestik maupun internasional. Pelayanan jasa bongkar muat di PT X dilakukan dalam waktu 24 jam sehingga perusahaan membuat 3 shift kerja dalam 1 hari. Pekerjaan bongkar muat petikemas di PT X yaitu mengangkat dan menurunkan petikemas dari kapal ke chassis truck maupun sebaliknya dengan menggunakan crane. Aktivitas bongkar muat dengan crane ini dilakukan oleh operator STS dan juru ikat. Pekerjaan bongkar muat dengan crane merupakan pekerjaan yang berisiko tinggi. Bahaya yang dapat terjadi kepada pekerja yaitu terjatuh, terpeleset, tertimpa material atau peti kemas, dan terjepit. Metode: Penelitian ini menggunakan rancangan cross sectional dengan pendekatan observasional. Variabel pada penelitian ini adalah identifikasi bahaya, penilaian risiko, pengendalian risiko, dan risiko sisa. Risk assessment dilakukan dengan menggunakan metode kualitatif. Data primer diperoleh dari observasi dan wawancara, sedangkan data sekunder diperoleh dari dokumen perusahaan. Hasil: Identifikasi bahaya pada aktivitas juru ikat didapatkan 1 potensi bahaya pada kategori risiko rendah, 11 potensi bahaya pada kategori risiko sedang, dan 10 potensi bahaya pada kategori tinggi. Simpulan: Terdapat banyak bahaya dengan risiko tinggi sebesar 45,45\% pada pekerjaan bongkar muat oleh juru ikat. Bahaya yang ditemukan pada kategori risiko tinggi yaitu tangan terjepit tali tambat, tertimpa petikemas, jatuh dari ketinggian, jatuh ke dalam palka, tertimpa twistlock, dan terkena lemparan twistlock.

Kata kunci: bongkar muat, juru ikat, risk assessment

\section{Author for Correspondence:}

Grace Stacyana

E-mail: gstacyana@gmail.com

Telephone: +6281246322553

\section{INTRODUCTION}

Occupational safety and health (hereafter, $\mathrm{OSH}$ ) is one endeavor to create a safe, healthy, and pollution-free work environment. For that reason, OSH needs to be developed, improved, and well-performed for workers or employees to be fully protected when doing their jobs. To achieve 
such goals, risk prevention, and risk control of occupational accidents and occupational illnesses are indispensable. These endeavors aim to increase work efficiency and productivity, as well as to prevent company loss, such as property or environmental damage in the workplace. The protection of employees, moreover, is regulated in the (Law of Republic Indonesia, 1970).

Occupational accidents are unexpected and unwanted occurrences that are detrimental to the environment, human beings, and property. The occupational accidents in port areas are likely caused by likelihood factors, for example, load characters, social elements, equipment, and work methods. The loss due to occupational accidents in port areas usually depends on the severity, such as injury, disability, death, and so on (Lasse, 2012).

According to the International Labour Organization (2013), approximately 250 million occupational accidents occurred, and 160 million workers suffered from occupational illnesses caused by the hazards in the workplace every year. Referring to the data of the Bureau of Labor Statistics (2008), in 2006 alone, 72 death cases of workers due to heavy equipment operation (crane) had been reported. The data further affirmed that most company that uses cranes are ports as the gate of international trade. PT. X in Surabaya is one of the ports that provide freight services both domestically and internationally.

These loading and unloading services involve riggers and heavy equipment, such as cranes (Ekasari, 2017). Minister of Transportation Decree (2002) on Implementation and Provision of Loading and Unloading Goods from and to A Ship Article 16 defined loading-unloading labor as the labor listed by a port to carry out loading-unloading services in the port. Riggers, the alias of loading-unloading labor, according to the Minister of Manpower and Transmigration Regulation (2010) are workers who have the ability and specialized skills in binding goods and helping the operation of lifting equipment.

Loading and unloading activities, similar to other businesses, also contain danger and risks. One of the cases of occupational accidents to a rigger happened in Jakarta International Container Terminal (JICT), where one rigger was found dead and floating on the sea. It was further reported that the worker completed the lasing release alone in the night time (Wilam, 2017).
Regarding the issue, many research has been conducted for the past decade, for example, a study conducted by Sanusi, Despriadi and Yusdinata (2017), which describes that the loading and unloading services performed by riggers contain high risks, such as hitting the ship walls, being hit by vehicles, and being struck down by materials. These risks are reported to be caused by a lack of awareness when in the workplace. Another research, for instance, the one conducted by Suryanto and Widajati (2017) on the relationship between the individual characteristics and the OSH supervision and the unsafe actions of the riggers. In results, they affirm that the main factors initiating the occupational accidents are lack of oversight, improper work equipment, and lack of Personal Protective Equipment (hereafter, PPE).

The loss caused by occupational accidents comprises both fatalities and the obstruction of the production process that leads to company loss. As stated by Ramli (2010), a loss can be divided into direct and indirect losses. The direct loss is in the form of death that the company needs to pay the medication and provide compensation. The indirect loss, on the other hand, can be in the form of the obstruction of the production process that can result in the products that are not following the predetermined target.

At PT. X, an occupational accident in the form of man cage damage due to being struck down by the ship hatch. According to the interview, it was revealed that the accident occurred by a lack of communication among workers; hence, not all workers were aware of the man cage in the ship hatch area. However, no fatalities were reported since no workers were present in the area when the accident occurred.

Due to the abundance of occupational accident cases in every workplace, the endeavor to prevent and reduce risks is necessary. The attempt can be made through hazard identification, risk assessment, and risk control by applying preventive, innovative, and participative approaches (Tarwaka, 2017). Based on the background elucidated above, this study aims to assess the risks in loading and unloading activity performed by the riggers at PT. X, Surabaya.

\section{METHODS}

This study had been performed in a container loading and unloading services company in Surabaya from March to May 2018. This study 
Table 1. AS/NZS 4360 Risk Management

\begin{tabular}{cccccc}
\hline \multirow{2}{*}{ Likelihood } & \multicolumn{5}{c}{ Severity } \\
\cline { 2 - 6 } & Insignificant (1) & Minor (2) & Moderate (3) & Major (4) & Catastrophic (5) \\
\hline 1 Rare & L (1) & L (2) & M (3) & H (4) & H (5) \\
2 Unlikely & L (2) & L (4) & M (6) & H (8) & E (10) \\
3. Possible & L (3) & M (6) & H (9) & E (12) & E (15) \\
4. Likely & M (4) & H (8) & H (12) & E (16) & E (20) \\
5.Almost certain & H (5) & H (10) & E (15) & E (20) & E (25) \\
\hline
\end{tabular}

L :Low Risk

M : Medium Risk

$\mathrm{H}$ : High Risk

E : Extreme Risk

is an observational study that applies the crosssectional design. The objects of this study consist of 30 riggers, six loading, and unloading supervisors, and three safety officers at PT. X, Surabaya.

The primary data of this study was obtained through direct observation and interview to the participants that is based on the Job Safety Analysis (JSA). Meanwhile, the secondary data were in the form of the company profile, work instruction, accident data, and the control by the company.

The variable analyzed was the hazard that may happen to the riggers during the container loading and unloading processes. The risks were assessed by determining the likelihood and severity levels (Standards Australia International, 2005). Both variables were then multiplicated to determine the risk level, as listed in Table 1. The obtained risk level was then analyzed and descriptively described through tables and narration along with the observation results. After that, the last step performed was to identify the controls implemented by the company to every identified hazard.

\section{RESULTS}

PT. $\mathrm{X}$ in Surabaya is a subsidiary of PT. Pelabuhan Indonesia III (Persero) that owns two docks: international dock and domestic dock. The container loading and unloading services from a ship to a chassis truck provided by the company are performed by using the Ship to Shore (STS) crane, which operation involves the STS operator and riggers. The riggers are divided into working groups known as the rigger "gang." The loading and unloading processes are performed 24 hours a day with the division of 4 groups (morning group, afternoon group, night group, and holiday group) and three shifts for seven working days.

\section{Hazard Identification}

The first step to identify the cause of occupational accidents in loading and unloading activities is hazard identification, particularly by applying the Job Safety Analysis (JSA) method. The JSA method is used to observe a work by identifying the hazards under the stages of work carried out and followed by the determination of the control needed to prevent or reduce the hazard possibilities. The first stage of work carried out by the riggers is mooring/ unmooring the ship's mooring rope. The ship crew throws the mooring rope to the riggers then is pulled and tied to the bolder on the dock. The ship then pulls the mooring rope to reach the dock.

After the ship anchors, the gangway from the ship or extra gangway is installed. Besides, the extra gangway is installed if the gangway cannot reach the port or if the ship position is too low. The installed gangway/extra gangway is used to board the ship for the workers to lash/unlash the container lock on the deck. The container lock, as Nugroho (2016) stated, is a 5-meters iron that is mounted across the front and the back of the container. The containers with an opened lock are then being installed with a twist lock, a prism-shaped iron lock mounted on all corners of a container so that the container will stay in place (Lasse, 2012). To open a twist lock, moreover, an 8-meter long iron rod called stick lashing is needed. After all the twist locks are opened, the containers are carried to the chassis truck on the dock by using a Ship to Shore (STS) crane to be brought to the field. In operating the crane, the STS operator is helped by the riggers through a handy talk (HT) or hand signal, especially in lifting and dropping the containers. Besides assisting the crane operator, the riggers should also open the twist locks when the containers are being lifted and put them in a gearbox. For the containers under the deck, furthermore, the ship hatch needs to be opened beforehand in these six activities carried out by the riggers at PT. X, Surabaya, start from mooring until 
Table 2. Risk Assessment at PT. X, Surabaya in 2018

\begin{tabular}{|c|c|c|c|c|c|}
\hline \multirow{2}{*}{ Type of Activity } & \multirow{2}{*}{ Potential Hazard } & \multirow{2}{*}{ Risk } & \multicolumn{2}{|c|}{ Risk Assessment } & \multirow{2}{*}{$\begin{array}{c}\text { Risk Level } \\
\text { (LxS) }\end{array}$} \\
\hline & & & $\mathbf{L}$ & $\mathbf{S}$ & \\
\hline \multirow{4}{*}{ Mooring/unmooring } & Being hit by the mooring rope & Scratches/bruises & 1 & 2 & 2 (Low) \\
\hline & Falling to the sea & Moderate injury & 1 & 3 & 3 (Moderate) \\
\hline & $\begin{array}{c}\text { Hands being squeezed by the mooring } \\
\text { rope }\end{array}$ & Moderate injury & 1 & 4 & 4 (High) \\
\hline & Broken mooring rope & Fracture/death & 1 & 5 & 5 (High) \\
\hline $\begin{array}{l}\text { Extra gangway } \\
\text { installation }\end{array}$ & Falling to the sea & Moderate injury & 1 & 3 & 3 (Moderate) \\
\hline \multirow{6}{*}{ Lashing/ unlashing } & Being tripped by the lashing bar & Bruises on the legs & 3 & 2 & 6 (Moderate) \\
\hline & Being punctured by the lashing tool & Scratches & 3 & 2 & 6 (Moderate) \\
\hline & Hands being squeezed & Torn wounds & 3 & 2 & 6 (Moderate) \\
\hline & Being struck down by the lashing tool & Bruises on the limbs & 2 & 3 & 6 (Moderate) \\
\hline & Falling to the sea & Serious injury & 1 & 3 & 3 (Moderate) \\
\hline & Being struck down by containers & Death & 1 & 5 & 5 (High) \\
\hline \multirow{4}{*}{$\begin{array}{l}\text { Twistlocks } \\
\text { installation on the } \\
\text { ship deck }\end{array}$} & Being tripped by the lashing bar & Bruises on the legs & 3 & 2 & 6 (Moderate) \\
\hline & Being struck down by the stick lashing & Moderate injury & 2 & 3 & 6 (Moderate) \\
\hline & Falling from the height & Serious injury/death & 1 & 5 & 5 (High) \\
\hline & Being struck down by containers & Death & 1 & 5 & 5 (High) \\
\hline \multirow{3}{*}{$\begin{array}{l}\text { Giving hand signals } \\
\text { to the STS operator } \\
\text { from the ship deck }\end{array}$} & Falling to the ship hatch & Serious injury/death & 1 & 5 & 5 (High) \\
\hline & Being hit by containers/ship hatch & Serious injury & 1 & 3 & 3 (Moderate) \\
\hline & Being struck down by the twist lock & Serious injury & 1 & 4 & 4 (High) \\
\hline \multirow{4}{*}{$\begin{array}{c}\text { Twistlocks } \\
\text { installation on the } \\
\text { dock }\end{array}$} & Hands being squeezed & Injury & 2 & 3 & 6 (Moderate) \\
\hline & Being struck down by containers & Death & 1 & 5 & 5 (High) \\
\hline & Being hit by thrown twist locks & Serious injury & 1 & 4 & 4 (High) \\
\hline & Being hit by moving vehicles & Serious injury/death & 1 & 4 & 4 (High) \\
\hline
\end{tabular}

putting the twist locks in a gearbox, a total of 22 hazards are identified.

In the mooring/unmooring activity alone, several hazards are listed. First, the workers that are lack of concentration might be hit by the mooring rope when thrown by the crew. Second, bad weather and strong wind might cause the workers to fall to the sea. Third, lack of coordination among workers when pulling the mooring rope might cause the hand pinched. Fourth, the non-proper mooring rope might be broken and reduce its effectivity.

For the extra gangway installation, the only identified hazard is the possibility to fall due to lack of coordination, loss of balance, and tripped by the bolder when carrying the extra gangway.

For the lashing/unlashing activities, six possible hazards have been identified. First, due to lack of concentration, the workers might be tripped by the lashing bar spread on the shipping deck. Second, the workers might be punctured by the sharp lashing tool as a result of rusty iron lock caused by corrosion.
Third, the workers' hand might be bound if less vigilantly buckling the turnbuckle and lashing bar. Fourth, the workers might be struck down by a lashing tool when being less vigilant in opening or locking the device; it might be slipped from the hand and hit the feet. Fifth, the workers might fall to the sea if they do not work according to the procedure or if they lose balance when lashing/unlashing near the sea. Sixth, the workers might be struck down by containers due to the flipper that is not adequately locked; it might slip from the spreader and hit the workers below.

In installing twist locks on the ship, four potential hazards are identified. First, the workers might be tripped by the lashing bar spread on the ship deck. Second, the workers might be struck down by the stick lashing twist locks if the container shakes. Second, the workers' had might be squeezed by rusty twist locks. Third, the workers might be struck down by the containers if the container drop to the chassis truck is not carried out correctly. 
Fourth, the workers might be hit by a thrown twist lock, since the twist locks left on the ship are usually thrown to the dock. Fifth, the workers might be hit by a moving vehicle, for example, the chassis truck or operational car.

\section{Risk Assessment}

After finishing the hazard identification on every mentioned activity, risk assessment is to be carried out. Risk assessment is a means used to control the risks and to ensure the safety of the workers in the workplace (Ridley, 2008). The determination of risk level is carried out by combining the likelihood and severity levels of each activity following the (Standards Australia International, 2005). The results of the risk assessment are displayed in Table 2.

\section{Risk Control}

Risk control is the next step to be performed after risk assessment to reduce the risk until reaching the acceptable level. PT. X, Surabaya, furthermore, has carried out risk control in several forms, such as engineering control, administrative control, and PPE control.

\section{DISCUSSION}

Tarwaka (2017) stated that according to the ALARP principle, unacceptable risk (or high risk) is a type of risk that needs to be controlled immediately to prevent harmful effects for the company. Tolerable risk, also known as medium risk, is a type of risk that needs further monitoring to determine the suitable control to minimize the loss.

\section{High Risk}

The hazard included as unacceptable risk (high risk) level of hazard in loading and unloading activities carried out by the riggers is being hit by moving vehicles when installing twist locks on the dock. By referring to the interview, the hazard is considered rare, with the severity level of 4 , given the risk is profoundly dangerous, and the likelihood level of 1 . The company, however, has regulated several controls regarding the hazard, such as installing lane markers, controlling the administration, for example, work instructions, safety briefing, signs provision to slow down, and controlling and requiring the PPE usage.

The hazard of falling to the sea is discovered in the activities of extra gangway installation, mooring/ unmooring, and lashing/unlashing, providing these activities require the workers to work near the sea. The risk of this hazard is in the form of serious injuries, with the severity and likelihood levels of 5 and 3 (possible), respectively. The company, regarding this matter, has provided several controls, for instance, safety briefing before working, supervision, work instructions, first aid kits, and clinic provisions. The PPE control, furthermore, is carried out by obligating the workers to wear a life vest when working.

The hazard of falling from the height is noticed in the activity of twist locks installation, with the risk of fracture and, in severe cases, death. The hazard obtains the severity level of 5 and the possiblelevel likelihood with a score of 3 . The controls provided by the company can be categorized into technical control and administrative control. The technical control comprises the use of man cage per the standard. The administrative control, on the other hand, includes the safety briefing, supervision, and the provisions of work instructions, first aid kits, and a clinic. The PPE control, moreover, is regulated through the requirement of wearing a full-body harness with a shock absorber.

The hazard of being struck down by containers or the ship hatch can be found in the activities of lashing/unlashing and twist locks installation, with the risk of death. This hazard obtains the severity and likelihood levels of 5 and 3 (possible), respectively. Even though the hazard comes with a high risk, the company has already provided control in the form of engineering control by regulating the lasher distance when unloading: 2 rows from the container.

\section{Medium Risk}

One of the tolerable risks in loading and unloading activities carried out by the riggers is being struck down by materials, which can be found in the activities of lashing/unlashing and twist locks installation. With a risk of bruises on the limbs, this hazard obtains the severity and likelihood levels of 3 and is categorized as a possible hazard. The control provided by the company includes supervision and the provision of work instructions and PPE, such as safety shoes and safety helmet.

The hazard of hands being squeezed is found in mooring/unmooring, lashing/unlashing containers, and twist locks installation with the risks vary from scratches to fractures. From the interview, it is perceived that the severity level obtains a score of 4 , while the likelihood level has a score of 3 
(unlikely). Thus, the company provides controls, such as supervision and communication among workers enhancement as well as the provisions of first aid kits and PPE.

The next hazard, broken mooring rope, is found in the mooring/unmooring activity. With the risk that varies from fracture to death, the hazard obtains the severity level of 4 and the likelihood level of 2. Due to this reason, the company has carried out control actions in the form of supervision and the provisions of work instructions and PPE.

The hazard of being hit by containers or the ship hatch occurs when the riggers are giving hand signals to the STS operator. The hazard obtains the severity level of 4 and the likelihood level of 3 with a risk of severe injuries and death. The company, however, has provided risk controls by carrying out supervisions and providing work instructions and PPE.

The hazard of being tripped is found in lashing/ unlashing activity with a risk of bruises on the limbs. The company provides control by providing first aid kits and PPE (safety shoes and helmet), given the severity and likelihood levels of the hazard obtain a score of 2 and 4, respectively.

The hazard of being hit by thrown materials, furthermore, is found during the twist locks installation on the dock. With a risk of serious injury, the hazard obtains the severity and likelihood levels of 3. The company, therefore, carries out the risk controls administratively by conducting safety briefing and supervision, giving work instructions, and providing first aid kits, a clinic, and PPE.

\section{CONCLUSION}

The loading/unloading activity carried out by the riggers consists of 6 stages, that is extra gangway installation, lashing/unlashing, twist locks installation on the ship deck, giving hand signals to the STS operator on the ship, and twist locks installation on the dock. From those stages, nine kinds of hazards have been identified, such as being hit, falling to the sea, falling from the height, being struck down by materials, being squeezed, broken mooring ropes, being hit by containers/ship hatch, and being hit by thrown twist locks. In the risk assessment, furthermore, it is found that there are ten hazards considered as unacceptable risk (high risk), 11 of tolerable risk (medium risk), and 1 of acceptable risk (low risk).

\section{ACKNOWLEDGMENT}

The biggest gratitude shall be addressed to my family and friends who give away their support and prayer for me that I can finish this study.

\section{REFERENCES}

Bureau of Labor Statistics (2008) Crane-Related Occupational Fatalities. Washington D.C.

Ekasari, L. E. (2017) 'Analisis Faktor yang Memengaruhi Kecelakaan Kerja pada Pengoperasian Container Crane di PT X Surabaya Tahun 2013-2015', The Indonesian Journal of Occupational Safety and Health, 6(1), pp. 124-133.

International Labour Organization (2013) Keselamatan dan Kesehatan Kerja : Sarana untuk Produktivitas. 5th edn. Jakarta: International Labour Organization.

Lasse, D. . (2012) Manajemen Muatan Aktivitas Rantai Pasok di Area Pelabuhan. Jakarta: Raja Grafindo Perkasa.

Law of Republic Indonesia (1970) Undang-Undang No. 1 Tahun 1970 tentang Keselamatan Kerja. Jakarta: President of Republic of Indonesia.

Minister of Manpower and Transmigration Regulation (2010) Nomor Per.09/MEN/VII/2010 tentang Operator dan Petugas Pesawat Angkat dan Angkut. Jakarta: Minister of Manpower and Transmigration of the Republic of Indonesia.

Minister of Transportation Decree (2002) KM 14 Tahun 2002 tentang Penyelenggaraan Dan Pengusahaan Bongkar Muat Barang Dari Dan Ke Kapal. Jakarta: The Minister of Transportation of the Republic of Indonesia.

Nugroho, N. (2016) Penilaian Risiko Pada Aktivitas Bongkar Muat Petikemas di PT X Surabaya. Undergraduate Thesis. Surabaya: Faculty of Public Health Universitas Airlangga.

Ramli, S. (2010) Pedoman Prakis Manajemen Risiko dalam Perspektif K3. Jakarta: Dian Rakyat.

Sanusi, S., Despriadi, A. and Yusdinata, Z. (2017) 'Analisa Potensi Bahaya dan Risiko Kegiatan Bongkar Muat di Pelabuhan PT Sarana Citranusa Kabil dengan Metode HIRARC', Jurnal Teknik Ibnu Sina, 2(1), pp. 119-125.

Standards Australia International (2005) Risk Management Guidelines Companion to AS/ NZS 4360:2004. Sydney: Standards Australia International, Ltd.

Suryanto, D. I. D. and Widajati, N. (2017) 'Hubungan Karakteristik Individu dan Pengawasan K3 
dengan Unsafe Action Tenaga Kerja Bongkar Muat', The Indonesian Journal of Public Health, 12(1), pp. 51-63.

Tarwaka (2017) Keselamatan dan Kesehatan Kerja: Manajemen Implementasi K3 di Tempat Kerja. Surakarta: Harapan Press.
Wilam (2017) Lagi Kecelakaan Kerja di JICT, Seorang TKBM Tewas Mengenaskan, Jakarta: Berita Trans. 